\title{
Improvement of the Method for Reconstructing the Temperature and Salinity Three-Dimensional Fields of the Black Sea Based on Insufficient Measurements and Altimetry
}

\author{
V.V. Knysh, P.N. Lishaev \\ Marine Hydrophysical Institute, Russian Academy of Sciences, Sevastopol, Russian Federation \\ e-mail:vaknysh@yandex.ru
}

\begin{abstract}
The article represents the results of two special numerical experiments aimed at improving the previously proposed procedure of reconstructing salinity and temperature three-dimensional fields based on the altimetry data and the insufficient measurements performed at the stations and the Argo buoys in 2012. In the Experiment 1, the monthly average coefficients of sea level linear dependence and depths where the salinity values of the "zero" gradation altimetry level profile lie within the salinity profiles of positive and negative gradations are applied. The procedure for calculating the daily average coefficients of the depth linear trends is realized in the Experiment 2. It is shown that the thermohaline fields reconstructed in the Experiment 2 for the deepwater area are more accurate; on the horizons of the 100-500 m layer their values range smoothly from one day to another. The Black Sea hydrophysical fields are reconstructed by assimilation in the model of three-dimensional thermohaline parameters in the reanalysis for 2012. It is revealed that, as compared to the observations on the overwhelming majority of horizons in the $0-500 \mathrm{~m}$ layer (the Experiment 2), the standard root-mean-square deviations of temperature and salinity are lower than those in Experiment 1 . The root of the measured salinity field dispersion exceeds the standard deviations on all the horizons within 0-500 m, inclusive. Application of the daily average coefficients of the linear trends for reconstructing three-dimensional fields of temperature and salinity, and their subsequent assimilation in the model is preferable. It is revealed that the model of the upper 0-100 m layer thermodynamics requires improvement.
\end{abstract}

Keywords: altimetry, Argo buoys, reconstruction procedure, coefficients of trends, three-dimensional fields, reanalysis

DOI: 10.22449/1573-160X-2016-6-3-14

(c) 2016, V.V. Knysh, P.N. Lishaev

(C) 2016, Physical Oceanography

Introduction. In order to improve the system functioning in Marine Hydrophysical Institute (MHI) in operative mode of nowcast, forecast and reanalysis of the Black Sea condition [1], it is necessary to develop a special procedure of temperature and salinity three-dimensional field reconstruction applying altimetry and rare contact measurements of these parameters performed at hydrologic stations and Argo buoys. Such sea measurements are characteristic for the period from 1993 to the present time. Solution of this problem is dictated by the fact that the results of circulation prolonged forecast calculations in the entire area of the sea according to MHI model [2] and short-term forecasts in the local coastal region according to high-resolution POM model [3 -6] point to inaccuracies in the reconstruction of the basin water average stratification. Inadequacy of turbulent exchange process parameterization, errors of atmospheric effect fields and approximate character of initial conditions may be the causes for them. Threedimensional temperature and salinity fields of sea water are not assimilated in the 
operative model [1]. They also were not applied in the most accurate (to date) reanalysis of the Black Sea hydrophysical fields for 1993 - 2012 period [7]. Deviation of temperature and salinity model profiles averaged over the horizons from the ones measured in the operative nowcast/forecast system is acquired assimilating in the model monthly average climatic profiles of thermohaline parameters. Annual average profiles of seawater temperature and salinity, calculated by V.N. Belokopytov according to rare measurements, were assimilated in the reanalysis [7]. They were corrected with regard to climate seasonal variability. It is necessary to improve a technique of such correction involving three-dimensional temperature and salinity fields. A procedure of reconstruction of diurnal three-dimensional thermohaline fields of the sea at certain horizons for 1993 - 2002 period was previously proposed in $[8,9]$.

The present paper is devoted to the analysis of numerical experiments on improvement of this procedure in order to increase the accuracy of both threedimensional temperature and salinity fields themselves and reconstruction of hydrophysical parameters with three-dimensional array assimilation in the model when performing the reanalysis over a single 2012. Statistical characteristics of accuracy of three-dimensional temperature and salinity fields calculated according to improved procedure and the ones reconstructed in the reanalysis are represented.

Reconstruction of the Black Sea three-dimensional temperature and salinity fields and the results of the reanalysis over 2012. Reconstruction procedure of three-dimensional fields of the Black Sea mentioned parameters, as is represented in [8,9], is based on original methodology of joint analysis of irregular in space and time and volume-limited measurement data of temperature, salinity and altimetry sea level fields. These fields are calculated for each day as a sum of level anomaly [9-13] values and annual mean climate level [14].

Numerical Experiment 1. The essence of method for three-dimensional temperature and salinity field reconstruction consists in measurement data referencing in $500 \mathrm{~m}$ isobath of abyssal sea part to the areas (gradations) of altimetry sea level lying between integer values of level isolines with $1 \mathrm{~cm}$ step (for instance, “-3, -2 ”, “-2, -1 ”, “-1, 0, 1”, “1, 2”, “2, 3”, .. cm). Temperature and salinity measurements carried out in the Black Sea in $1993-2012$ at hydrologic stations and Argo floating buoys were composed by V.N. Belokopytov by months and were vertically interpolated at the following horizons of numerical model [2]: $2,5,5,10,20, \ldots, 50,63,75,88,100,113,125,150,175,200,250,300,400, \ldots$, $2100 \mathrm{~m}$. Each measured seawater temperature (salinity) profile belongs to one or another sea level gradation corresponding to the point and time of probing. Temperature and salinity profiles are accumulated during three calendar months for statistical sufficiency. Then they are averaged and attributed to an average month. For the next month accumulation was carried out in the same time interval but it was shifted one month forward. As a result, we obtain one monthly average temperature profile and one monthly average salinity profile for each level gradation and for each month of 2012. Particular attention should be given to temperature and salinity profiles of "zero" level gradation (“-1, 0, 1" cm) which are characterized as unperturbed profiles of these parameters. 
An assumption (mentioned in [9]) on the fact that from certain depths it is possible to introduce the notion of slowly changing over time and horizontally homogeneous basic stratification of the basin temperature $T(z)$ and salinity $S(z)$ (density) fields is confirmed by the analysis of $T, S$-curves constructed according to the data of monthly average temperature and salinity profiles for "zero" (Fig. 1) and for all other level gradations (see Fig. 4 in the paper [9]). Temperature and salinity (measured at the stations) by which monthly average profiles were obtained, are marked by circles in Fig. 1 . Scatter of measurements around $T, S$ curves decreases from $50-100 \mathrm{~m}$ depths and does not depend on coordinates and time of probing. The Black Sea water mass with $50-100 \mathrm{~m}$ upper boundary and $1100-1200$ lower one is commonly called the Black Sea intermediate water mass $[15,16]$. Distortions of isopycnic, isothermal and isohaline surface topography caused by the effect of wind or synoptic variability occur in $100-500$ m layer of deepwater basin mostly in adiabatic way, with no irreversible changes of the basic stratification. Such evolution of isosurface topography is observed in wide range of spatial-temporal scales: from one week to several years [17, 18].
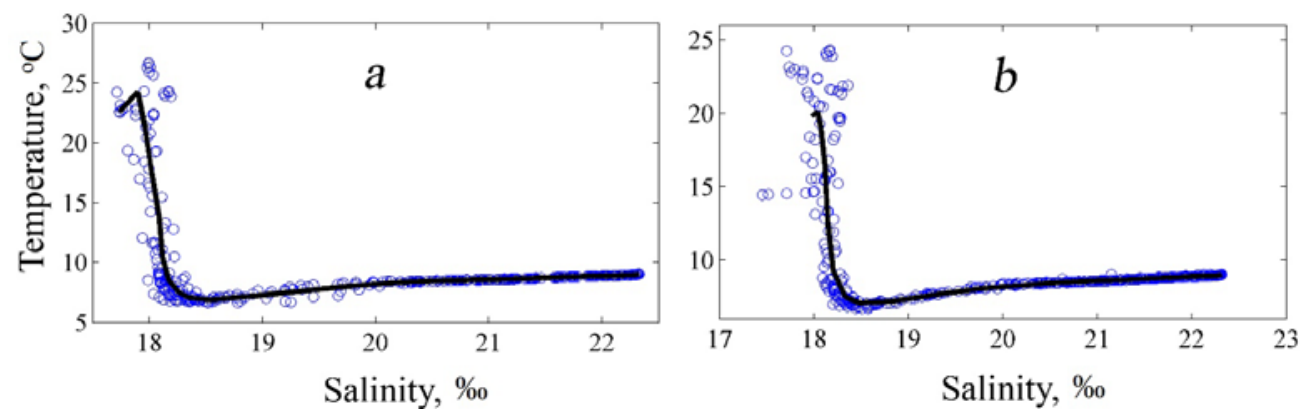

Fig 1. T, S-curves (solid lines) of “zero" level gradation for 2012: $a$ - August; $b$ - October

Unperturbed temperature and salinity profiles were taken as basic in accordance with the procedure of calculating three-dimensional temperature and salinity fields [9]. Displacements of isohaline surfaces (salinity depth of monthly average "zero" gradation profile in monthly average salinity profiles of positive and negative altimetry sea level gradations) were determined by means of linear interpolation at the horizons in $100-500$ m layer for all the months of 2012 . Monthly diagrams of dependences of isohaline location depth variation on level gradations for each monthly average profile of unperturbed salinity $S_{0}$, as well as an approximation of the dependences by linear function of the form

$$
h\left(S_{0}, \zeta\right)=a\left(S_{0}\right) \zeta+b\left(S_{0}\right),
$$

where $h\left(S_{0}, \zeta\right)$ is a isohaline location depth, $\zeta$ is a diurnal value of altimetry sea level, $a\left(S_{0}\right), b\left(S_{0}\right)$ are the known coefficients (Fig. 2, $b$ ), allowed us to reconstruct diurnal three-dimensional salinity fields for all months of 2012 [9]. Temperature profile reconstruction was carried out using $T, S$-curves constructed according to monthly average temperature and salinity profiles of "zero" level gradation.

Three-dimensional temperature and salinity fields of the Black Sea abyssal part (bounded by $500 \mathrm{~m}$ isobath) were reconstructed at regular grid of MHI model [2] with uniform horizontal step of $5 \mathrm{~km}$. To assess the statistical characteristics of accuracy of 
reconstructed fields the deviations from the observations carried out in the Black Sea abyssal part in 2012 were found at each horizon of $100 \mathrm{~m}-500 \mathrm{~m}$ layer.

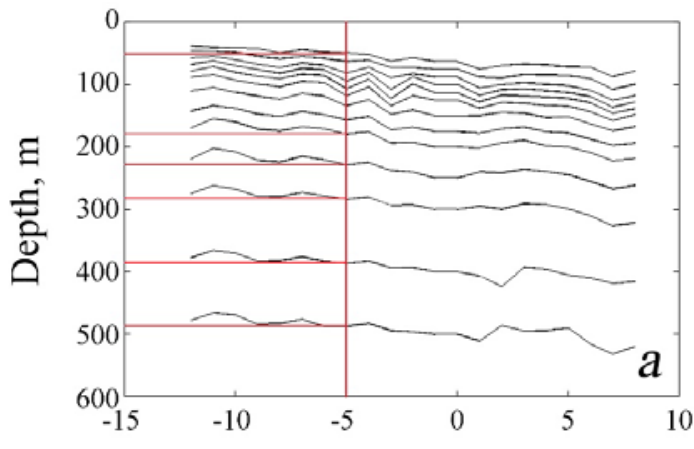

Sea Level, cm

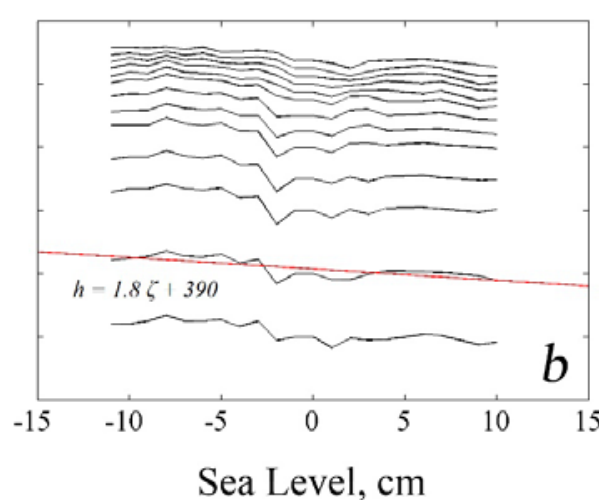

Sea Level, cm

Fig. 2. Diagrams of $h$ depths dependence on sea level gradations in the horizons of $63-500 \mathrm{~m}$ layer for 2012: $a$ - May; $b$ - August

It is obvious from Tab. 1 that the values of root-mean-square deviations (RMSD) of reconstructed temperature and salinity decrease in $100-500$ m layer. The root of dispersion of measured temperature and salinity fields exceeds RMSD by the layer horizons and indicates that the reconstructed fields are quite acceptable.

T a ble 1

Standard Root-mean-square Deviations (RMSD) of the Temperature and Salinity Fields Reconstructed in the Model and Root $(\sigma)$ of Dispersion of these Fields Measured by the Horizons within 2012 (Experiment 1)

\begin{tabular}{c|c|c|c|c}
\hline \multirow{2}{*}{ Horizon, $\mathrm{m}$} & \multicolumn{2}{|c|}{ Temperature, ${ }^{\circ} \mathrm{C}$} & \multicolumn{2}{c}{ Salinity, \%o } \\
\cline { 2 - 5 } & RMSD & $\sigma$ & RMSD & $\sigma$ \\
\hline 100 & 0.2082 & 0.3209 & 0.3455 & 0.6165 \\
113 & 0.1158 & 0.1845 & 0.2854 & 0.5043 \\
125 & 0.0643 & 0.1209 & 0.2248 & 0.4142 \\
150 & 0.0380 & 0.0654 & 0.1370 & 0.2485 \\
175 & 0.0310 & 0.0448 & 0.0947 & 0.1606 \\
200 & 0.0271 & 0.0372 & 0.0744 & 0.1206 \\
250 & 0.0169 & 0.0240 & 0.0539 & 0.0726 \\
300 & 0.0104 & 0.0143 & 0.0373 & 0.0478 \\
400 & 0.0044 & 0.0061 & 0.0206 & 0.0274 \\
500 & 0.0047 & 0.0069 & 0.0129 & 0.0169 \\
\hline
\end{tabular}

As the reconstructed temperature and salinity are known in each point of grid domain and are linked to the level values, their assimilation in the model in the retrospective analysis for 2012 was carried out using the simplest method [19, 20]: the inclusion of $Q_{T}, Q_{S}$ sources into the right parts of transport - diffusion equations of heat and salt. These sources are of the following form:

$$
\begin{array}{r}
Q_{T}(\vec{x}, t)=1 / \operatorname{REL}\left[1+\eta_{T}{ }^{2}\left(z, t_{\text {month }}\right)\right]\left[T^{\text {obs }}(\vec{x}, t)-T(\vec{x}, t)\right], \\
Q_{S}(\vec{x}, t)=1 / \operatorname{REL}\left[1+\eta_{S}{ }^{2}\left(z, t_{\text {month }}\right)\right]\left[S^{\text {obs }}(\vec{x}, t)-S(\vec{x}, t)\right],
\end{array}
$$


where $\vec{x}=(x, y, z)$; REL is relaxation parameter; $\eta_{T}{ }^{2}\left(z, t_{\text {month }}\right), \eta_{S}{ }^{2}\left(z, t_{\text {month }}\right)$ are monthly average measure of measurement errors which are the ratio of monthly average temperature and salinity RMSD square to the dispersion of natural variability of corresponding fields [19]; $T^{\text {obs }}(\vec{x}, t), S^{\text {obs }}(\vec{x}, t)$ are three-dimensional temperature and salinity fields reconstructed according to the measurements; $T(\vec{x}, t), S(\vec{x}, t)$ are temperature and salinity model values. The coefficients of vertical turbulent momentum exchange and vertical turbulent diffusion of heat and salt were determined according to Philander - Pakanowski formula [21, 22]. The values of parameters selected in it are represented in [2]. Atmospheric effect was assigned according to ERA-Interim reanalysis results [23]. Initial time moment corresponded to 00 a.m. January 1 2012. Temperature, salinity, sea level and current velocity fields reconstructed in the analysis for $1993-2012$ with the assimilation in the monthly average temperature and salinity profiles of "zero" altimetry level gradation [24] were taken as initial ones. Relaxation parameter was equal to 3 days. Reanalysis data for 2012 included daily average fields of horizontal and vertical components of current velocity, temperature and salinity on 38 horizon, as well as sea level.

Table 2

\section{Standard Root-mean-square Deviations (RMSD) of the Temperature and Salinity Fields Reconstructed in the Model and Root $(\sigma)$ of Dispersion of these Fields Measured by the Horizons within 2012 (Experiment 1)}

\begin{tabular}{c|c|c|c|c}
\hline \multirow{2}{*}{ Horizon, m } & \multicolumn{2}{|c|}{ Temperature, ${ }^{\circ} \mathrm{C}$} & \multicolumn{2}{c}{ Salinity, \%o } \\
\cline { 2 - 5 } & RMSD & $\sigma$ & RMSD & $\sigma$ \\
\hline 3 & 1.5833 & 5.3295 & 0.1669 & 0.1700 \\
5 & 1.7391 & 6.3366 & 0.1990 & 0.2515 \\
10 & 2.3509 & 6.4515 & 0.1703 & 0.2052 \\
15 & 3.7044 & 5.5025 & 0.1375 & 0.1778 \\
20 & 4.5832 & 4.5608 & 0.1114 & 0.1429 \\
25 & 4.0227 & 3.7581 & 0.1125 & 0.1246 \\
30 & 2.7879 & 2.3938 & 0.1222 & 0.1166 \\
40 & 1.6959 & 0.9456 & 0.1756 & 0.2052 \\
50 & 0.9057 & 0.6691 & 0.2933 & 0.4165 \\
63 & 0.6039 & 0.6546 & 0.3887 & 0.6304 \\
75 & 0.4851 & 0.6238 & 0.4222 & 0.7066 \\
88 & 0.3891 & 0.4831 & 0.4124 & 0.6960 \\
100 & 0.3040 & 0.3209 & 0.3805 & 0.6165 \\
113 & 0.2417 & 0.1845 & 0.3470 & 0.5043 \\
125 & 0.1555 & 0.1209 & 0.2935 & 0.4142 \\
150 & 0.0695 & 0.0654 & 0.1772 & 0.2485 \\
175 & 0.0431 & 0.0448 & 0.1175 & 0.1606 \\
200 & 0.0340 & 0.0372 & 0.0903 & 0.1206 \\
250 & 0.0223 & 0.0240 & 0.0620 & 0.0726 \\
300 & 0.0142 & 0.0143 & 0.0410 & 0.0478 \\
400 & 0.0077 & 0.0061 & 0.0249 & 0.0274 \\
500 & 0.0053 & 0.0069 & 0.0145 & 0.0169 \\
\hline
\end{tabular}


Tab. 2 shows that the RMSD simulated in the reanalysis of temperature fields reaches its maximum value on $20 \mathrm{~m}$ horizon and decreases with depth. Standard deviation of the measured temperature has greater values in the upper layer of 0 $30 \mathrm{~m}$ and exceeds the temperature RMSD calculated in the model on the horizons within $0-15 \mathrm{~m}$. Salinity RMSD maximum was obtained in the main halocline layer on the horizon of $75 \mathrm{~m}$. The root of the measured salinity field dispersion turned to be greater than the RMSD of model salinity on the horizons within $0-500 \mathrm{~m}$, that indicates a greater accuracy of the salinity fields reconstructed in the reanalysis.

Since in the present case the formation of hydrophysical fields in the layer of $0-100 \mathrm{~m}$ is determined primarily by the quality of the model and atmospheric effect field, statistical characteristics indicate that the thermodynamics of upper sea layer is simulated inaccurately in the model.

Examples of assimilated salinity field and hydrophysical fields restored in reanalysis are shown in Fig. 3, $a-c$. Anticyclonic eddies to the right of the Black Sea Rim Current, as well as cyclonic structures, are clearly monitored in the salinity and horizontal velocity fields in accordance with the characteristic structures of altimetric sea level (Fig. 3, $d$ ). In the dipole eddy system Sevastopol anticyclone - cyclone the location of the latter is slightly displaced southward as compared with the altimetry data (Fig. 3, $a-d$ ). The reason of this displacement is, apparently, the inaccurate simulation of the sea fields in the southwest of Tarkhankut Cape.
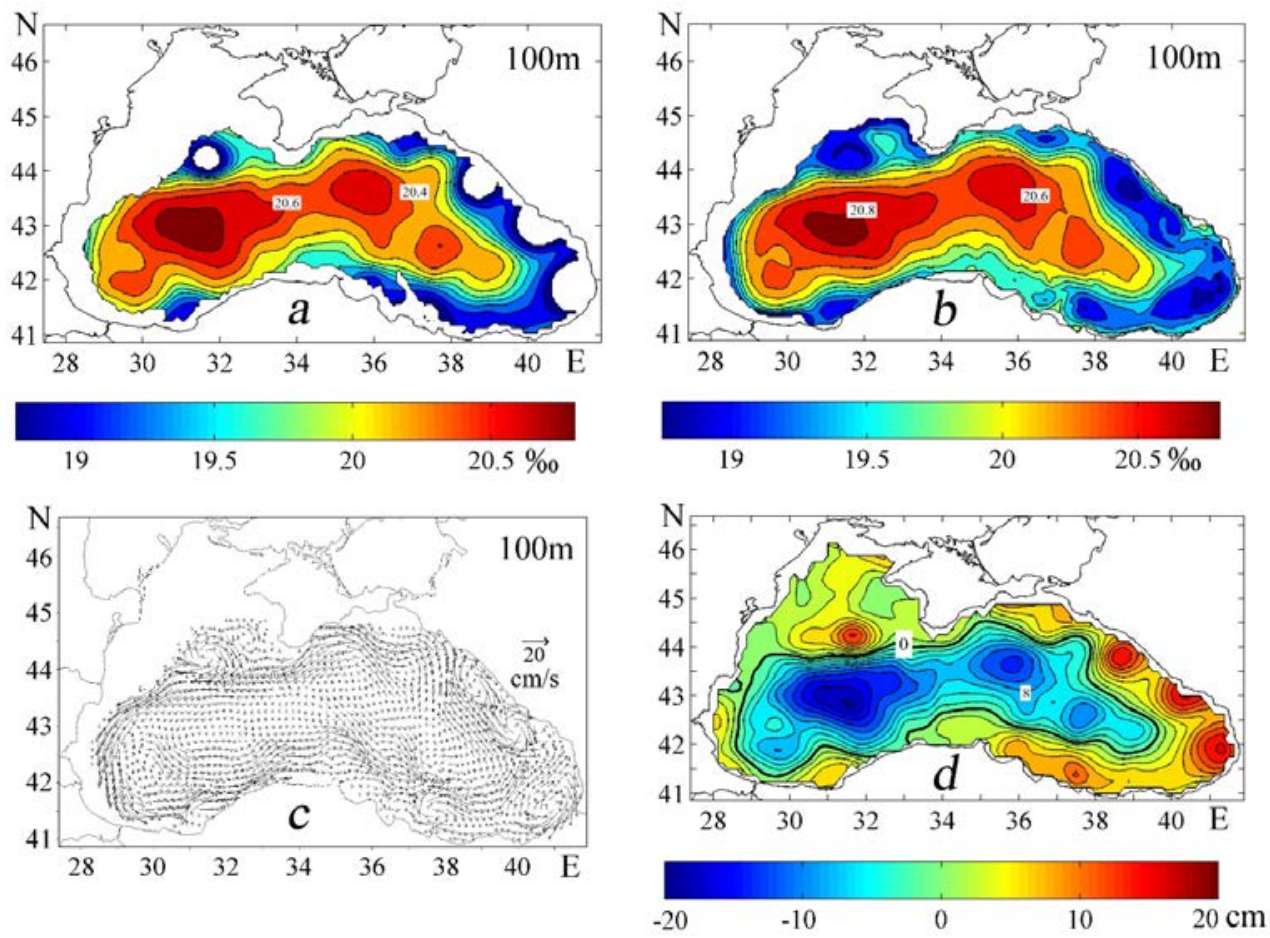

Fig. 3. Reconstructed in the Experiment 1 for 1.05.2012: salinity according to the measurements and altimetry $(a)$; salinity $(b)$ and currents $(c)$ by the reanalysis; altimetric level topography $(d)$ 
Numerical Experiment 2. The disadvantage of assimilated three-dimensional temperature and salinity fields in the model, reconstructed in the numerical experiment 1 , is the abrupt change of the range of spatial variability values on the horizons when passing from month to month. This is particularly noticeable in the months when the coefficient $a\left(S_{0}\right)$ is changing very rapidly (Fig. 4, $a$ the black line). The reason for this range of temperature (salinity) values is the use of monthly mean coefficients $a\left(S_{0}\right), b\left(S_{0}\right)$ - for calculation of the depth $h$ according to the the formula (1) and the subsequent reconstruction of three-dimensional fields of the mentioned model parameters on the horizons.
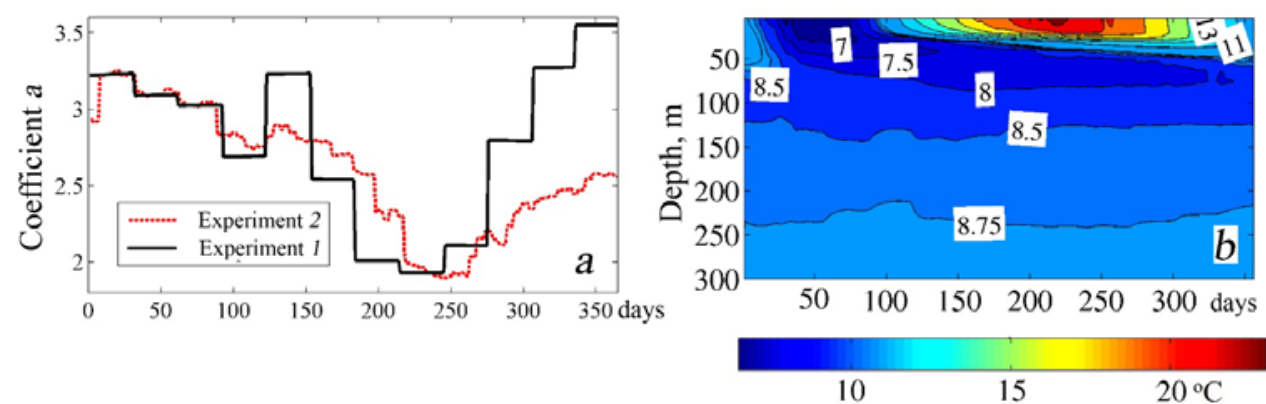

Fig. 4. Temporal variability of the mean monthly (Experiment 1) and mean daily (Experiment 2) values of the coefficient $a$ on the horizon of $100 \mathrm{~m}(a)$, including the season variability diagram of the temperature average over horizons in the layer of $0-300 \mathrm{~m}(b)$ during 2012

In the present experiment we use the time interval $(t-45, t+45$ days) to accumulate salinity (temperature) profiles in each gradation of altimetric sea level. Then the profiles are averaged and referred to the fixed days $t$. Further the diurnal shift, accumulation of salinity (temperature) profiles, their averaging and assignment to the following days are carried out. In the result we obtain a profile of salinity and one of temperature for each gradation level and for every day during 2012. The unperturbed daily salinity and temperature profiles are taken as the reference ones. The difference from the Experiment 1 was that the calculation of the depths $h$ according to the formula (1) to restore three-dimensional temperature and salinity fields on the model horizons the daily values of the coefficients $a\left(S_{0}\right)$ and $b\left(S_{0}\right)$ were applied. Fig. $4, a$ shows that the red line corresponding to the experiment 2 is smoother. As a result, the range of reconstructed salinity (temperature) variations on the model horizons within $100-500 \mathrm{~m}$ smoothly varies when passing from one day to another.

The thermohaline fields reconstructed in the Experiment 2 have greater accuracy than in the Experiment 1 (data is not shown).

The reanalysis for 2012 was carried out with the model assimilation of the 2 sets of temperature and salinity reconstructed in the Experiment 2. According to its results, the statistical characteristics of accuracy of the reconstructed sea hydrophysical fields were evaluated. It was found that the RMSD between the model and the measured values of the temperature, as shown on Tab. 2 and 3, were less (except $75 \mathrm{~m}$ ) than in Experiment 1 on all the horizons within $0-500 \mathrm{~m}$. The same result was obtained by RMSD of the salinity fields with some horizons of 5 88 m layer excluded. 
Table 3

Standard Root-mean-square Deviations (RMSD) of the Temperature and Salinity Fields Reconstructed in the Model and Root ( $\sigma$ ) of Dispersion of these Fields Measured by the Horizons within 2012 (Experiment 1)

\begin{tabular}{c|c|c|c|c}
\hline \multirow{2}{*}{ Horizon, $\mathrm{m}$} & \multicolumn{2}{|c|}{ Temperatuire, ${ }^{\circ} \mathrm{C}$} & \multicolumn{2}{c}{ Salinity, \%o } \\
\cline { 2 - 5 } & RMSD & $\sigma$ & RMSD & $\sigma$ \\
\hline 3 & 1.4669 & 5.3295 & 0.1461 & 0.1700 \\
5 & 1.6789 & 6.3366 & 0.2052 & 0.2515 \\
10 & 2.3340 & 6.4515 & 0.1698 & 0.2052 \\
15 & 3.6821 & 5.5025 & 0.1388 & 0.1778 \\
20 & 4.5629 & 4.5608 & 0.1112 & 0.1429 \\
25 & 4.0000 & 3.7581 & 0.1074 & 0.1246 \\
30 & 2.6865 & 2.3938 & 0.1152 & 0.1166 \\
40 & 1.5531 & 0.9456 & 0.1729 & 0.2052 \\
50 & 0.8094 & 0.6691 & 0.3119 & 0.4165 \\
63 & 0.5965 & 0.6546 & 0.4195 & 0.6304 \\
75 & 0.4974 & 0.6238 & 0.4222 & 0.7066 \\
88 & 0.3876 & 0.4831 & 0.4261 & 0.6960 \\
100 & 0.2391 & 0.3209 & 0.3394 & 0.6165 \\
113 & 0.1441 & 0.1845 & 0.2932 & 0.5043 \\
125 & 0.0915 & 0.1209 & 0.2410 & 0.4142 \\
150 & 0.0468 & 0.0654 & 0.1374 & 0.2485 \\
175 & 0.0330 & 0.0448 & 0.0914 & 0.1606 \\
200 & 0.0274 & 0.0372 & 0.0777 & 0.1206 \\
250 & 0.0178 & 0.0240 & 0.0501 & 0.0726 \\
300 & 0.0109 & 0.0143 & 0.0334 & 0.0478 \\
400 & 0.0059 & 0.0061 & 0.0183 & 0.0274 \\
500 & 0.0053 & 0.0069 & 0.0124 & 0.0169 \\
\hline
\end{tabular}

Root of the measured temperature field dispersion exceeds the RMSD almost on all the horizons, except 20, 25, 30, 40 and $50 \mathrm{~m}$. In a similar vein, the same statistical parameter of the salinity was greater than RMSD on the horizons within up to $500 \mathrm{~m}$ inclusive.

Crucially, according to the model data, the values of temperature RMSD on the horizons within $0-100 \mathrm{~m}$ are greater (Tab. 3). Taking into account the fact that the formation of the thermohaline fields in this layer is mainly determined by the quality of the model and atmospheric effect fields (data of measurements in this layer can not be processed), it is possible to conclude that there is a lack of accuracy in modeling of thermodynamics of the sea upper layer. The complex nature of the thermodynamic processes developing in this layer is demonstrated on the pattern of advection mechanism of the cold intermediate layer (CIL) [25, 26]. In Fig. $4, b$ the CIL formation processes are clearly shown as follows: autumnwinter water cooling, the formation of the upper quasi-homogeneous layer (UQL), the spring-summer water warming and the seasonal thermocline formation and the formation of a new CIL, its cold content lowering by autumn and continuity disturbance. According to the data in [27] (Tab. 7.1), a significant renewal of the 
sea CIL is characteristic for 2012. Fig. 5 clearly demonstrates the cold water having a temperature of $5 \leq T \leq 8{ }^{\circ} \mathrm{C}$ and a lower salinity, resulting from the autumn-winter cooling of the surface layer in the north-western shelf. As shown in [26], cooling and winter convection leads to increase of the UQL thickness. So, cold water layers are moving to the open sea and merge with the old CIL waters. Further, the renewed CIL waters are transported by the Rim Current in the southwest, south and south-east and then, in the north-west by the Rim Current east jet (Fig. 5, $a, b$ ). As a result, with the renewed water displacement the structures of temperature and salinity fields are transformed. Such structures are less pronounced in the anticyclonic eddies and in cyclonic gyres within $0-100 \mathrm{~m}$ layer. There through, the drop in the model in the sea level reconstructed in the model and the intensity of anticyclonic eddies were too low in comparison with altimetry level (Fig. 5, $c$ and Fig. 3, d).

As shown in Fig. 3, $c$ and Fig. 5, d, sea water circulation reproduced in the Experiments 1 and 2 varies slightly. Also, Kizilirmak, Batumi, two Caucasian anticyclones, including Sevastopol anticyclonic cyclonic eddies observed in the Experiment 2 in the eastern part of the sea, should be noted.
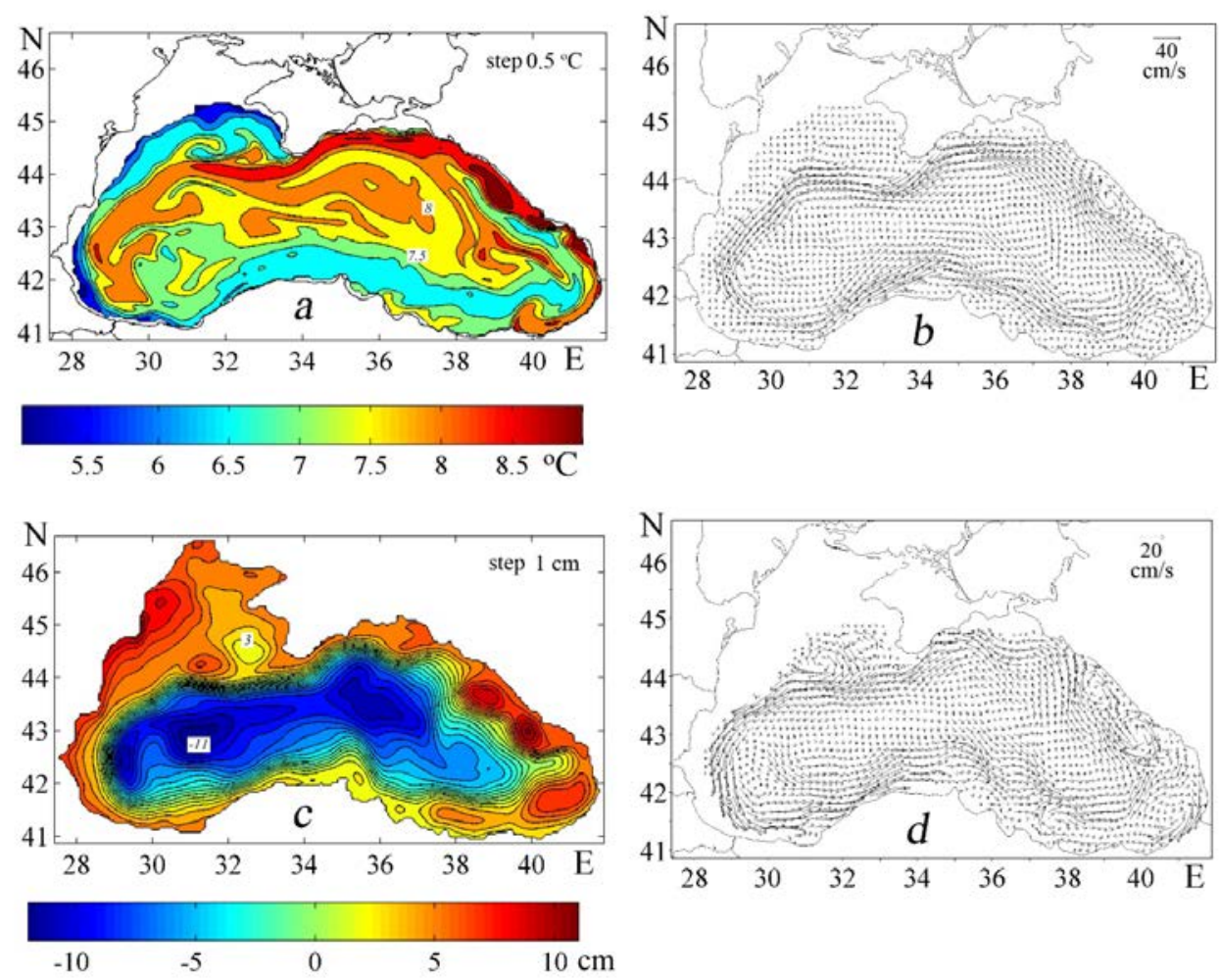

Fig. 5. Reconstructed in the Experiment 2 by the reanalysis: temperature $(a)$ and currents $(b)$ on $50 \mathrm{~m}$ horizon on 31.03.2012; sea level topography $(c)$ and currents on $100 \mathrm{~m}$ horizon $(d)$ on 1.05 .2012

Conclusion. Clarification of the previously proposed procedure of reconstructing three-dimensional fields of the Black Sea salinity and temperature was carried out analyzing the results of two special numerical experiments. In the

PHYSICAL OCEANOGRAPHY NO. 6 (2016) 
Experiment 1 , the monthly average coefficients $a\left(S_{0}\right)$ and $b\left(S_{0}\right)$ were applied, in the Experiment 2 - their average daily ones. In the latter experiment on the horizons of the $100-500 \mathrm{~m}$ layer their values range smoothly from one day to another. The thermohaline fields reconstructed in the Experiment 2 for the deepwater area are more accurate. The root-mean-square deviations between the values calculated in the reanalysis for 2012 and the measured salinity values on the horizons in the 0 - $500 \mathrm{~m}$ layer (except some horizon within $0-100 \mathrm{~m}$ ) turned to be lower than in the Experiment 1. The standard root-mean-square deviations of temperature and salinity were lower than those in the Experiment 1 on all the horizons within $0-500 \mathrm{~m}$, excluding $75 \mathrm{~m}$ horizon. It is revealed that the model of the upper $0-100 \mathrm{~m}$ layer thermodynamics requires improvement. Application of the daily average coefficients of the linear trends for reconstructing threedimensional fields of temperature and salinity, and their subsequent assimilation in the model is preferable.

The research was carried out within the framework of State Order No. 08272014-0011 "Research the laws of changes of the marine environment based on operational observations and marine water diagnosis prediction and status reanalysis system data”, including the RFBR Grant No. 16-05-00621.

\section{REFERENCES}

1. Korotaev, G.K., Demyshev, S.G. \& Dorofeev, V.L. [et al.], 2013, “Arhitektura i rezul'taty raboty Mezhdunarodnogo Chernomorskogo centra morskih prognozov, sozdannogo na baze MGI NAN Ukrainy v ramkah proekta Evropejskogo Soyuza "Moj Okean” [Architecture and results of work of the Black Sea Marine Forecast Center established on the basis of MHI NAS of Ukraine within the framework of European Commission project MyOcean”], Ekologicheskaya bezopasnost' pribrezhnoy i shel'fovoy zon i kompleksnoe ispol'zovanie resursov shel'fa, iss. 27, pp. 128-133 (in Russian).

2. Lishaev, P.N., Korotaev, G.K. \& Knysh, V.V. [et al.], 2014, "Vosstanovlenie sinopticheskoy izmenchivosti gidrofizicheskikh poley Chernogo morya na osnove reanaliza za 1980-1993 gody [Reconstruction of Mesoscale Variability of the Black Sea Hydrophysical Fields on the Basis of Reanalysis for 1980-1993]”, Ekologicheskaya bezopasnost' pribrezhnoy i shel'fovoy zon i kompleksnoe ispol'zovanie resursov shel'fa, no. 5, pp. 49-68 (in Russian).

3. Ratner, Yu.B., Kubryakov, A.I. \& Kholod, A.L. [et al.], 2014, “Ispol'zovanie dannykh izmereniy s dreyfuyushchikh buev SVP-BTS i Argo dlya validatsii rezul'tatov prognoza temperatury vody v pribrezhnoy oblasti Chernogo morya [The usage of SVP-BTS and Argo drifting buoy data for validation of water temperature forecast results in the Black Sea coastal area]”, Morskoy gidrofizicheskiy zhurnal, no. 5, pp. 33-48 (in Russian).

4. Kubryakov, A.I., 2004, "Primenenie tekhnologii vlozhennykh setok pri sozdanii sistemy monitoringa gidrofizicheskikh poley $v$ pribrezhnykh rayonakh Chernogo morya [The use of technology to create nested grids in the creation of monitoring system of hydrophysical fields in the Black Sea coastal areas]”, Ekologicheskaya bezopasnost' pribrezhnoy i shel'fovoy zon $i$ kompleksnoe ispol'zovanie resursov shel'fa, Sevastopol, iss. 11, pp. 31-50 (in Russian).

5. Blumberg, A.F., Mellor, G.L., 1987, “A description of a three-dimensional coastal ocean model. Three Dimensional Shelf Models”, Coast. Estuar. Sci. V. 5, Washington D.C., AGU, pp. 1-16.

6. Hunter, J.R., 2002, “OzPOM: A version of the Princeton Ocean Model”, http://www. antcrc. utas.edu.au/johunter/ozpom.html. 
7. Dorofeev, V.L., Sukhih, L.I., 2016, “Analysis of Variability of the Black Sea Hydrophysical Fields in 1993 - 2012 Based on the Reanalysis Results”, Physical Oceanography, no. 1, pp. 33-47, doi: 10.22449/1573-160X-2016-1-33-47

8. Korotaev, G.K., Lishaev, P.N. \& Knysh, V.V., 2015, "Technique of the Black Sea Temperature and Salinity Measurement Data Analysis Using Dynamic Altimetry Level”, Physical Oceanography, no. 2, pp. 24-38, doi: 10.22449/1573-160X-2015-2-24-38

9. Korotaev, G.K., Lishaev, P.N. \& Knysh, V.V., 2016, “Vosstanovlenie trekhmernykh poley solenosti i temperatury Chernogo morya po dannym sputnikovykh al'timetricheskikh izmereniy [Reconstruction of Three-Dimensional Fields of Temperature and Salinity Based on Satellite Altimetry]”, Issledovanie Zemli iz kosmosa, no. 1-2, pp. 199-212 (in Russian).

10. AVISO - Archivage Validation Interprétation des données des Satellites Océanographiques, http://www.aviso.oceanobs.com/.

11. Le Traon, P. Y., Dibarboure, G. \& Ducet, N., 2001, "Use of a high-resolution model to analyze the mapping capabilities of multiple-altimeter missions", J. Atmos. Ocean. Technol., vol. 18, no. 7, pp. 1277-1288, doi: 10.1175/1520-0426(2001)018<1277:IUOHARM>2.0.CO;2

12. Pascual, A., Faugère, Y. \& Larnicol, G. [et al.], 2006, "Improved description of the ocean mesoscale variability by combining four satellite altimeters”, Geophys. Res. Lett., vol. 33, no. 3, P. 2611-2614.

13. Kubryakov, A.A., Stanichny, S.V., 2013, "Estimating the quality of the retrieval of the surface geostrophic circulation of the Black Sea by satellite altimetry data based on validation with drifting buoy measurements”, Izvestiya. Atmos. Ocean. Phys., vol. 49, no. 9, pp. 930938.

14. Knysh, V.V., Kubryakov, A.I. \& Inyushina, N.V. [et al.], 2008, "Vosstanovlenie klimaticheskoy sezonnoy tsirkulyatsii Chernogo morya na osnove modeli $v$-koordinatakh $s$ ispol'zovaniem assimilyatsii dannykh o temperature i solenosti [The Black Sea seasonal climatic circulation renewal based on the model in $\sigma$-coordinates applying temperature and salinity data assimilation]", Ekologicheskaya bezopasnost' pribrezhnoy i shel'fovoy zon i kompleksnoe ispol'zovanie resursov shel'fa, vol. 16, pp. 243-265 (in Russian).

15. Leonov, A.K., 1960, "Regional'naya okeanografiya. Chast' 1. Beringovo, Okhotskoe, Yaponskoe, Kaspiyskoe i Chernoe morya [Regional oceanography. Part 1: the Bering, Okhotsk, Japan, Caspian and Black Sea]”, Leningrad, Gidrometeoizdat, 765 p. (in Russian).

16. Ivanov, V.A., Belokopytov, V.N., 2011, "Okeanografiya Chernogo morya [The Black Sea Oceanography]”, Sevastopol, ECOSI-Gidrofizika, 209 p. (in Russian).

17. Korotaev, G., Dorofeev, V. \& Oguz, T. [et al.], 2011, “The MyOcean Black Sea coupling of dynamics and ecosystem”, Mercator Ocean Quart. Newslet., vol. 40, pp. 26-35.

18. Kubryakov, A.A., Stanichny, S.V., 2015, "Seasonal and interannual variability of the Black Sea eddies and its dependence on characteristics of the large-scale circulation”, Deep-Sea Res. Part I: Ocean. Res. Papers, vol. 97, pp. 80-91, http://dx.doi.org/10.1016/j.dsr.2014.12.002.

19. Gandin, L.S., Kagan, R.A., 1976, "Statisticheskie metody interpretatsii meteorologicheskikh dannykh [Statistical methods for the meteorological data interpretation]”, Leningrad, Gidrometeoizdat, 357 p. (in Russian).

20. Sarmiento, J.L., Bryan, K., 1982, “An ocean transport model for the North Atlantic”, J. Geoph. Res., vol. 87, iss. C1, pp. 394-408, doi:10.1029/JC087iC01p00394

21. Pacanowski, R.C., Philander, S.G.H., 1981, "Parameterization of vertical mixing in numerical models of tropical oceans”, J. Phys. Oceanogr., no. 11, pp. 1443-1451, doi: 10.1175/15200485(1981)011<1443:POVMIN>2.0.CO;2

22. Ibraev, R.A., Trukhchev, D.I., 1998, "Model study of the seasonal variability of the Black Sea circulation”, NATO TU, Black Sea project ecosystem modeling as a management tool for Black Sea, symposium on Scientific results, Dordrecht, Kluwer Academic Publishers, vol. 2, pp. 179-196.

23. Berrisford, P., Dee, D. \& Fielding, K. [et al.], 2009, “The ERA-Interim archive Version 1.0”, ERA Rep. Ser.-ECMWF, 16 p., www.ecmwf.int. 
24. Korotaev, G.K., Sarkisyan, A.S. \& Knysh, V.V. [et al.], 2016, "Reanalysis of seasonal and interannual variability of Black Sea fields for 1993-2012”, Izvestiya. Atmos. Ocean. Phys., vol. 52, iss. 4, pp. 418-430, doi: 10.1134/S0001433816040071

25. Kolesnikov, A.G., 1953, "K vychisleniyu godovogo khoda temperatury vody $v$ yuzhnykh moryakh [On the calculation of the annual water temperature variation in the Southern seas]", Tr. Morskogo gidrofizicheskogo instituta AN SSSR, vol. 3, pp. 106-127 (in Russian).

26. Korotaev, G.K., Knysh, V.V. \& Kubryakov, A.I., 2014, "Study of formation process of cold intermediate layer based on reanalysis of Black Sea hydrophysical fields for 1971-1993", Izvestiya. Atmos. Ocean. Phys., vol. 50, iss. 1, pp. 35-48.

27. Ilyin, Y.P., Repetin, L.N., \& Belokopytov, V.N. [et al.], 2012, “Gidrometeorologicheskie usloviya morey Ukrainy. T. 2. Chernoe more [Ukrainian Hydrometeorological conditions of the seas. Vol. 2. The Black Sea]”, Sevastopol, ECOSI-Gidrofizika, 420 p. (in Russian). 